5. Концепції загальноосвітньої галузі «Основи виробництва» («Технології») [Електронний ресурс] // Концепції профільного навчання в старшій школі. - Режим доступу: http://uazakon.com/document/fpart93/idx93094.htm. - Заголовок 3 екрану. 6. Крутецкий В. А. Психология обучения и воспитания школьников: учебник / В. А. Крутецкий. - М. : Просвещение, 1976. - 304 с. 7. Леви В. Л. Искусство быть собой / В. Л. Леви. - М. : Знание, 1977. - 208 с. 8. Моляко В. А. Психологічна готовність до творчої праці / В. А. Моляко. - К. : Знання, серія 7 «Педагогічна»,1989. - № 9. 9. Теплов Б.М. Способности и одарённость. Проблемы индивидуальных различий. - М.: Изд-во МГУ. - 1961 10. Философский словарь / под ред. М. М. Розенталь. - Изд. 3-е. - М. : Политиздат, 1972. - 496 с. 11. Фрейд 3. Психология бессознательного : сб. призведений / З. Фрейд. - М. : Просвещение, 1990. - 448 с.

УДК 378.091.313:004.77

Юлія Кулінка

\title{
МЕТОДОЛОГІЧНІ АСПЕКТИ ВПРОВАДЖЕННЯ ВЕБ-КВЕСТ-ТЕХНОЛОГЇ̈ ЯК ВИДУ ПРОЕКТНОЇ ДІЯЛЬНОСТІ ДЛЯ ПІДВИЩЕННЯ ЯКОСТІ ОСВІТИ
}

Кулінка Ю. С. Методологічні аспекти впровадження веб-квест-технології як виду проектної діяльності для підвищення якості освіти

У статті обгрунтовано особливості впровадження та використання однієї 3 інформаційно-комунікативних технологій - веб-квест, що розглядається автором як вид проектної діяльності на уроках трудового навчання під час вивчення варіативного модуля «Технологія заготівлі та зберігання продуктів» у 9 класі.

Ключові слова: інформаційно-комунікативні технології, веб-квест-технології, веб-квест, інтернет-ресурс, інтернет-сайт, презентація веб-квесту.

Кулинка Ю. С. Методологические аспекты внедрения веб-квест-технологий как вида проектной деятельности для повышения качества образования.

В статье обоснованы особенности внедрения и использования одной из видов информационно-коммуникативных технологий - веб-квест, которая рассматривается автором как вид проектной деятельности на уроках трудового обучения при изучении вариативного модуля «Технология заготовки и сохранения продуктов» в 9 классе.

Ключевые слова: информационно-коммуникативные технологии, веб-квесттехнологии, веб-квест, интернет-ресурс, интернет-сайт, презентация веб-квеста.

Kulinka Yu. S. Methodological aspects of introducing web-quest technologies as a type of project activity to improve the quality of education

The article shows some aspects of introducing and using one of informationalcommunicative technologies - a web quest, which the author considers as a type of project activity at home economy classes while studying the module «Technology of storing and preserving food» in the $9^{\text {th }}$ grade.

Key words: informational-communicative technologies, web-quest technologies, webquest, the Internet resources, Internet site, presentation of a web-quest.

Модернізація освіти, що базується на нових інформаційних технологіях, передбачає формування нових моделей навчальної діяльності, що використовують інформаційні засоби навчання. Сучасна національна школа знаходиться у процесі пошуку оптимальних форм i методів навчання. Формування нових моделей навчальної діяльності з широким використанням інформаційних технологій навчання 
є головним складником модернізації освіти.

Зростає інтерес до механізмів залучення підростаючого покоління до діяльності, що сприяє розвитку здібностей учнів. Життя показує, що формування будь-якої компетентності відбувається через практичну діяльність. Такими механізмами $\epsilon$ технології навчання. Цей процес неможливий без розвитку технологій освіти 3 використанням різних сервісів мережі Інтернет і розповсюдження електронних освітніх ресурсів.

Сучасна навчальна програма вимагає від учнів уміння працювати з інформацією, потік якої постійно зростає. Це вдається далеко не всім. Часто ми спостерігаємо, що учні відчувають значні труднощі, не впевнені у своїх силах, не задоволені результатами своєї праці. Це призводить до втрати інтересу під час вивчення предметів як гуманітарного, так і природничого циклу.

Тому проблема збереження і розвитку навчальної мотивації школярів завжди була і буде актуальною. Учителям треба підтримувати інтерес учнів, створювати такі умови, коли кожен учень залучений до творчої діяльності, що сприяє не тільки продуктивності навчання, але й гуманізації освіти. Досвід роботи показує, що найбільш ефективним є метод проектів, що передбачаєє використання активних форм, у тому числі й у позаурочній діяльності.

Нині у всіх школах більшість учнів вільно користується сучасними інформаційними технологіями, що, звичайно, спрощує для них процес пошуку інформації, іiі оброблення та надання в різних формах. Тому використання у проектній діяльності учнів комп'ютера як інструменту творчої діяльності сприяє досягненню кількох завдань: підвищення мотивації до самонавчання, формування нових компетенцій, реалізація креативного потенціалу, підвищення особистісної самооцінки, розвиток незатребуваних у навчальному процесі особистісних якостей (наприклад, поетичні, музичні, художні здібності).

Розвиток комп'ютерних технологій, особливо інформаційно-комунікативних, дає потужний імпульс розвитку підростаючого покоління. Зважаючи на це, доцільним $\epsilon$ використання веб-квестів як виду проектної діяльності на уроках трудового навчання.

Аналіз попередніх досліджень свідчить, що термін «веб-квест» походить від англ. Web- пошук у мережі або інтернет-пошук і Quest- це інтелектуальнодинамічна гра, що полягає у проходженні командою вказаного маршруту і передбачає виконання спеціальних завдань. Розробниками веб-квесту як навчального завдання $\epsilon$ американські вчені Б. Додж та Т. Марч, російські Є. Полат, Я. Биховський, Н. Ніколаєва, А. Хуторський та ін. Серед вітчизняних дослідників упровадженням технології веб-квест займаються Р. Гуревич, М. Кадемія, Н. Кононец та ін.

Mema cmammi - обгрунтувати доцільність використання веб-квест-технологій як виду проектної діяльності на уроках трудового навчання.

Активне використання на уроках інтернет-технологій, телекомунікаційних засобів дозволяє говорити про впровадження інноваційних процесів, за допомогою яких відбуваються зміни різного характеру: змінюється мета і зміст навчальних планів, форми й методи навчання.

Веб-квест як освітня технологія спирається на такий підхід до навчання, у процесі якого відбувається конструювання нового. Згідно з цим підходом, учитель виконує незвичну роль - стає консультантом, організатором i координатором проблемно-орієнтованої, дослідницької, навчально-пізнавальної діяльності учнів. Учителем створюються умови для самостійної розумової і творчої діяльності учнів і підтримується їхня ініціатива. У свою чергу, учні - це рівноправні «співучасники» процесу навчання, які поділяють зі своїм учителем відповідальність за процес і 
результати навчання.

Веб-квестом називається спеціальним чином організований вид дослідницької діяльності, для виконання якої учні здійснюють пошук інформації в мережі Інтернет за вказаними адресами. Веб-квести створюються для того, щоб учні вчилися використовувати отриману інформацію з практичною метою, ця технологія сприяє розвитку критичного мислення, аналізу, синтезу й оцінки інформації.

Отже, веб-квест поєднує в собі ідеї проектного методу та ігрових технологій в інтернет-середовищі засобами веб-технологій.

Згідно $з$ аналізом літератури [1-3], веб-квест - це захоплююча подорож мережею Інтернет, що припускає запити в різних пошукових системах, одержання досить значного обсягу інформації, іiі аналіз, систематизацію і подальшу презентацію. Це технологія, що дозволяє працювати в групах, розвиває конкурентність і лідерство. По суті, веб-квест - це інтерактивний процес, під час якого учні самостійно здобувають необхідні знання. Роботу за технологією веб-квест можна використовувати скрізь, де $\epsilon$ вихід в Інтернет, незалежно від навчального предмета, що вивчається.

Щоб дана робота була максимально ефективною, веб-квест повинен містити такі складники:

- вступ, у якому описуються терміни проведення і задається початкова ситуація;

- цікаве завдання, що можна реально виконати;

- набір покликань на ресурси мережі, необхідні для виконання завдання. Деякі (але не всі) ресурси можуть бути скопійовані на сайт цього веб-квеста, щоб полегшити таким чином викачування матеріалів. Вказані ресурси повинні містити посилання на web-сторінки, електронні адреси експертів або тематичні чати, книги або інші матеріали, наявні в бібліотеці або у вчителя. Завдяки вказівці точних адрес під час виконання завдань учні не витрачатимуть зайвого часу на пошук інформації;

- опис процесу виконання роботи. Він повинен бути розподілений на етапи і 3 вказівкою конкретних термінів;

- деякі пояснення щодо оброблення отриманої інформації: спрямовуючі питання, дерево понять, причино-наслідкові діаграми;

- висновок, який нагадує, що вивчали, чого вони навчилися, виконуючи це завдання; можливо, шляхи для подальшої самостійної роботи за темою або опис того, яким чином можна перенести отриманий досвід в іншу галузь [2].

Веб-квести найкраще підходять для роботи в міні-групах, проте існують і вебквести, призначені для роботи окремими учнями. Форми веб-квеста також можуть бути різними. Найбільш популярні такі:

- Створення бази даних з проблеми, всі розділи якої готують учні.

- Створення мікросвіту, у якому учні можуть пересуватися за допомогою гіперпокликань, моделюючи фізичний простір.

- Написання інтерактивної історії (учні можуть вибирати варіанти продовження роботи; для цього кожного разу вказуються два-три можливі напрями).

- Створення документа, що дає аналіз якої-небудь складної проблеми і запрошує учнів погодитися або не погодитися з думкою авторів.

- Інтерв'ю on-line з віртуальним персонажем. Відповіді і питання розробляються учнями, що глибоко вивчили цю особу. (Це може бути політичний діяч, літературний персонаж, відомий науковець, інопланетянин). Такий варіант роботи краще всього пропонувати не окремим учням, а міні-групі, одержуючи загальну оцінку (яку пропонують решта учнів і вчитель) за свою роботу.

- Робота $з$ веб-квестами може бути запропонована і як домашнє завдання для 
учнів, які цікавляться предметом, їі можна провести в класі за наявності спарених уроків. Добрий результат цей вид діяльності забезпечує під час підготовки до олімпіад, оскільки розширює світогляд та ерудицію. Реальне розміщення веб-квестів у мережі у вигляді web-сайтів, створених самими школярами, дозволяє значно підвищити мотивацію учнів та досягнення кращих навчальних результатів.

Науковці виокремили три критерії для класифікації веб-квестів:

За тривалістю виконання: короткострокові та довгострокові.

За предметним змістом: монопроекти, міжпредметні веб-квести.

3a типом завдань, які виконують учні: переказ, компіляційні загадки, журналістські, конструкторські, творчі, переконуючі, розв’язок спірних проблем, самопізнавальні, аналітичні, оцінні, наукові [1;3].

Завдання на переказ $є$ найбільш примітивними i становлять найпростіший приклад використання інтернету як джерела інформації та вважається веб-квестом за таких умов:

- формат i форма доповідей учнів відрізняється від оригіналів матеріалів, матеріал тексту не $є$ простим копіюванням тексту з Інтернету в текстовий редактор;

- учні вільні у виборі того, про що розповідають і яким чином організують знайдену інформацію;

- учні використовують навички збирання, систематизації та оброблення інформації [1].

Сутність компіляційного завдання полягає в тому, що учні мають взяти інформацію з різних джерел і привести іï до єдиного формату. Підсумкова компіляція може бути опублікована в мережі Інтернет або представлена у вигляді нецифрового продукту, наприклад, книгою.

Веб-квест, що створений на основі завдання-загадки, потребує синтезу інформації з набору джерел і створення головоломки, що неможливо розв'язати простим пошуком відповіді на сторінках мережі Інтернет. Навпаки, необхідно придумати загадку, розв'язання якої потребує:

- засвоєння інформації з багатьох джерел;

- зведення інформації в єдине ціле за допомогою висновків, узагальнень з різних джерел інформації;

- виключення хибних відповідей, що спочатку уявлялися правильними, а у процесі розгляду стали хибними.

У журналістських веб-квестах учні мають зібрати факти та представити їх у жанрі репортажу новин, інтерв'ю і тощо.

Конструкторський веб-квест потребує від учнів створення продукту або плану 3 виконання раніше визначеної мети в певних межах.

Творчий веб-квест вимагає від учнів створення продукту в заданому форматі. Творчі проекти подібні конструкторським, проте є вільними і непередбачуваними в своїх результатах. У процесі оцінки таких проектів необхідно більше уваги приділяти творчості й самовираженню учнів.

Веб-квести з розв'язання спірних проблем передбачають пошук і представлення різних, а інколи суперечливих думок 3 однієї проблеми і спробу привести їх до консенсусу. Отже, веб-квест як вид проектної діяльності має низку позитивних чинників, що впливають на розвиток учнів і відображені на рис. 1.

У результаті навчання за цією технологією учні повинні створити власний вебквест - веб-сторінку (окремий документ у мережі Інтернет, що має свою адресу) чи веб-сайт (групу взаємопов'язаних веб-сторінок, присвячених конкретній тематиці). 
Задля формування мотивів навчальної діяльності під час вивчення варіативного розділу програми у 9 класі «Технологія зберігання і заготівлі продуктів» учням пропонується виконання веб-квесту. Мета веб-квесту: формування мотивів навчальної діяльності, розвиток умінь пошуку, перероблення та представлення інформації з теми в електронному форматі.

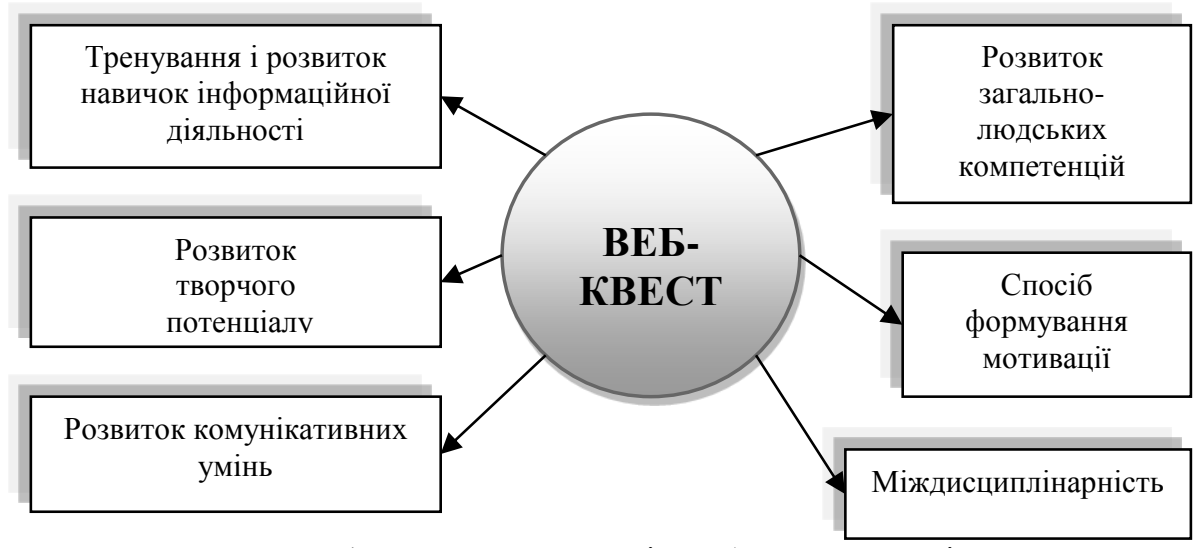

Рис. 1. Методичний потенціал веб-квест технологій

У завданні до веб-квесту вказуються групи i ролі учасників проекту, визначаються форми представлення кінцевого результату. Школярам пропонується розподілитися по групах, кожна 3 них у своїй роботі відображає одну 3 позицій, у контексті якої проводиться вивчення варіативного модуля «Технологія заготівлі та зберігання продуктів». Обираючи групи, учні можуть орієнтуватися на свої здібності, інтереси, вподобання та нахили, або ж, навпаки, спробувати себе у «незвичній для себе ролі». Наводимо орієнтовний зразок інструкції веб-квесту.

Веб-квест "Технологія заготівлі та зберігання продуктів»

\begin{tabular}{|c|c|c|c|c|c|}
\hline Спрямованість & $\begin{array}{c}\text { Технологія } \\
\text { заготівлі та } \\
\text { зберігання } \\
\text { продуктів }\end{array}$ & Кількість & 15-18 учнів & Вік учнів & \\
\hline Тип & Веб-квест & & \begin{tabular}{|l|} 
Місце \\
проведення
\end{tabular} & \multicolumn{2}{|c|}{$\begin{array}{l}\text { Комп’ютерний клас } 3 \\
\text { доступом до інтернету }\end{array}$} \\
\hline Автор & \multicolumn{5}{|c|}{$\begin{array}{l}\text { Кулінка Юлія Сергіївна (старший викладач кафедри педагогіки та } \\
\text { методики технологічної освіти КПІ ДВНЗ «КНУ») } \\
\text { Романова Катерина Олексіївна (студентка } 5 \text { курсу ТПФ) }\end{array}$} \\
\hline Завдання & \multicolumn{5}{|c|}{$\begin{array}{l}\text { Mетодичні завдання: сформувати мотиви навчальної діяльності; } \\
\text { активізувати пізнавальну діяльність учнів; розвивати } \\
\text { комунікативні, креативні здібності } \text { учнів; виховувати } \\
\text { зацікавленість обраним модулем. } \\
\text { Уміння та навички, ще формуються: пошук, оброблення та } \\
\text { використання інформації; вміння користуватися комп'ютером, } \\
\text { працювати з інтернет-ресурсами, створювати веб-сайт у Microsoft } \\
\text { FrontPage, презентації у PowerPoint та буклету Publisher. }\end{array}$} \\
\hline Результат & \multicolumn{5}{|c|}{$\begin{array}{l}\text { Створення локального веб-сайту у Microsoft FrontPage. Створення } \\
\text { презентацій у межах обраної дисципліни та загальної презентації }\end{array}$} \\
\hline
\end{tabular}




\begin{tabular}{|c|c|c|c|c|c|}
\hline Спрямованість & \begin{tabular}{|c|} 
Технологія \\
заготівлі та \\
зберігання \\
продуктів
\end{tabular} & Кількість & 15-18 учнів & Вік учнів & $\begin{array}{l}14-15 \\
\text { років }\end{array}$ \\
\hline & \multicolumn{5}{|c|}{ веб-квесту. Створення рекламного буклету } \\
\hline Ресурси & \multicolumn{5}{|c|}{ Комп’ютер з мережею Інтернет } \\
\hline Інтернет-ресурси & \multicolumn{5}{|c|}{ 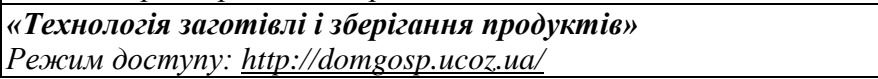 } \\
\hline
\end{tabular}

\section{Орієнтовні розділи веб-квесту:} сторінці.

1. $\boldsymbol{B} \boldsymbol{c m y n}-$ короткий опис теми веб-квесту. Доцільно розмістити на Домашній

\section{2. Новини.}

3. Цікаво прочитати (подивитись).

4. Потрібно знати.

5. Використані матеріали - сторінка, яка містить покликання на інтернетресурси, що використовувалися для створення веб-квесту.

6. Обов'язково передбачити сторінку Розробники веб-квесту. На сторінках освітнього веб-квесту розмістити розроблені учасниками проекту презентації.

\section{Порядок роботи:}

1. Розбийтеся на групи по 3 особи в кожній.

2. Кожен $з$ членів групи повинен обрати собі одну з ролей. У кожного - своя роль, ролі не повинні повторюватися! Кожна роль передбачує виконання певних завдань, упоратися з якими вам допоможуть інтернет-ресурси. Після виконання всіх завдань члени групи звітують про проведену роботу, обговорюють їі результати.

Ролі: Теоретики. Ваше завдання: вивчити інтернет-ресурси 3 теорії консервування: якість сировини для консервування; способи консервування харчових продуктів; тара та упаковка для консервування.

Інтернет-ресурси з теорії консервування:

http://uk.wikipedia.org/wiki;

http://agrobiznes.org.ua/node/280;

http://kuking.net/8_261.htm;

http://vkus.by/index.php?a=118;

http://zdorovo-tak.ru/sposoby-koservacii.html

Технологи. Вам потрібно вивчити за допомогою інтернет-ресурсів історію консервування; технологію домашнього консервування; загальні прийоми консервування.

Інтернет-ресурси з технології консервування:

http://znaimo.com.ua/;

http://ktoperviy.ru/eda/sposoby-konservacii-ryby.html;

http://www.xliby.ru/kulinarija/domashnee_konservirovanie/p2.php;

http://kuking.net/8_261.htm;

http://www.smakota.org.ua/;

http://www.youtube.com/; http://www.coolreferat.com/

Дослідники. Вам необхідно дослідити дуже важливу тему - поживна цінність продуктів рослинного та тваринного походження, їх значення в раціоні людини; відсоток вітамінів та мінералів, що зберігаються після технологічної обробки.

Інтернет-ресурси з поживної цінності продуктів рослинного та тваринного походження:

http://ua-referat.com/; http://max-body.ru/raznoe/spravochnaja-informacija/; 
http://ua.textreferat.com/referat-1167.html;

http://otherreferats.allbest.ru/;

http://womanadvice.ru/konservirovannye-persiki;

http://www.coolreferat.com/.

Комп ютерний технолог. Ваше завдання: за допомогою технічних засобів розробити мультимедійну презентацію.

Інтернет-ресурси з мультимедіа-презентаціями:

http://images.yandex.ua/;

http://www.youtube.com/;

http://video.yandex.ua/\#top;

http://gotovim-doma.ru/view.php?g=6

Отже, досвід показав, що методика веб-квест користується високою популярністю в сучасних учнів, активізує їх, сприяє підвищенню якості навчання. Веб-квест - це вид проектної діяльності, в межах якої вчитель формує пошукову діяльність школярів, задає їм параметри цієї діяльності й визначає ії час. Означена технологія перетворює учнів з пасивних об'єктів навчальної діяльності в їі активних суб'єктів, підвищує мотивацію до процесу «здобування» знань.

Отже, веб-квест технологія - це сукупність методів та прийомів організації дослідницької діяльності, для виконання якої учні на уроках трудового навчання здійснюють пошук інформації, використовуючи інтернет-ресурси 3 практичною метою. Така технологія дозволяє працювати в групах, розвиває конкурентність та лідерські якості школярів, підвищує не тільки мотивацію до процесу здобування знань, а й відповідальність за результати діяльності та їх презентацію. Цю технологію можна використовувати незалежно від навчальної дисципліни, головне - мати доступ до Інтернету.

\section{Література}

1. Быховский Я. С. Образовательные веб-квесты / Я. С. Быховский [Электронный ресурс]. - Режим доступа : http: // ito.edu.ru 2. Кононец Н. Технологія веб-квест у контексті ресурсно-орієнтованого навчання студентів/ Н. Кононец // Витоки педагогічної майстерності: збірник наукових праць Полтавського національного педагогічного університету імені В.Г. Короленка. - Вип. 10. Полтава, 2012. - Серія «Педагогічні науки». - С. 138-143. 3. Трайнев В. А. Информационные коммуникационные педагогические технологии (обобщение и рекомендации) : [учеб. пос.] / В. А. Трайнев, И. В. Трайнев. - М. : Изд.-торг. корп. «Дашков и Ко», 2008. - 280 с.

\section{АКТИВІЗАЦІЯ ПІЗНАВАЛЬНОЇ ДІЯЛЬНОСТІ УЧНІВ НА УРОКАХ ТРУДОВОГО НАВЧАННЯ: РЕЗУЛЬТАТИ ЕКСПЕРИМЕНТУ}

Сушенцев О. С. Активізація пізнавальної діяльності учнів на уроках трудового навчання: результати експерименту.

У статті автор розкриває хід дослідно-експериментальної роботи 3 перевірки визначених теоретичним шляхом педагогічних умов активізації пізнавальної діяльності учнів основної школи на уроках трудового навчання.

Ключові слова: активізація пізнавальної діяльності, пізнавальна активність, пізнавальна самостійність, трудове навчання. 